\title{
Impact resistance analysis of grille dam based on fluid structure interaction
}

\author{
Jia $\mathrm{Zhu}^{1,2^{*}}$ \\ ${ }^{1}$ School of civil engineering, Lanzhou University of Technology, Lanzhou, Gansu 730050, China \\ ${ }^{2}$ Western Center for Disaster Mitigation in Civil Engineering of Ministry of Education, Lanzhou University of Technology, Lanzhou \\ 730050, China
}

\begin{abstract}
Aiming at the impact failure of debris flow grille dam, considering the interaction of boulderdebris flow slurry- grille dam based on SPH-FEM, this article analyzed the variation laws of velocity, impact force and support reaction before and after debris flow slurry and boulders passing through grille dam. The results show that: SPH-FEM coupling method can truly reappear the impact of debris flow on the grille dam; the velocity of debris flow slurry and boulder are reduced by nearly $60 \%$ after passing through the dam, and the effect is remarkable; debris flow slurry and boulder have secondary impact on the grille dam. In the first impact, the greater the radius of the boulder, the greater the impact force; in the second impact, the impact force has nothing to do with the radius of the boulder.
\end{abstract}

\section{Introduction}

China [1] is one of the countries with the widest distribution, the largest number and the most serious harm of debris flow in the world. Especially in the western region, debris flow disasters occur frequently, causing serious loss of people's lives and property. At present, the engineering control structure is the most effective means to mitigate the debris flow disaster, and scholars have done a lot of research on it. Yong Zhou [2] established the dynamic equation between debris flow impact load and gravity grille dam by using structural dynamics method, and analyzed the dynamic response of grille dam. Yonghong Ran [3] studied the dynamic performance of concrete-filled steel tubular pile forest under impact load through experiments. Jiang $\mathrm{Xu}$ [4] used the fluid structure coupling theory to simulate the gravity grille dam impacted by debris flow, and obtained the distribution law of stress and displacement of the grille dam. Chun Liu [5] established a three-dimensional coupling numerical model and analyzed the dynamic behavior of the gravity dam. Shuai Feng [6] used FLAC3D to analyze the ultimate punching resistance of the pile sheet wall grille structure of Long daban gully debris flow.
To sum up, scholars have carried out a lot of research work on debris flow control works, and achieved abundant results. However, most of the research on the prevention structure only considers the impact of boulders, or simply superimposes the load of debris flow slurry and boulders linearly, without considering the coupling of the two, which is obviously inconsistent with the actual situation. This text studied the impact resistance of grille dam based on the coupling model of debris flow slurry, boulder and grille dam.

\section{Establishment of finite element model for grille dam}

When modeling, the slope at the bottom of the river is $0.2 \mathrm{~m}$ and the width is $9 \mathrm{~m}$. There are 6 boulders in the model, and the radius of boulders are $0.2 \mathrm{~m}, 0.3 \mathrm{~m}, 0.4 \mathrm{~m}$ and $0.5 \mathrm{~m}$. The height of the grille dam is $6 \mathrm{~m}$, the width is $9 \mathrm{~m}$, the grille column spacing is $1.08 \mathrm{~m}$, and the grille beam spacing is $0.65 \mathrm{~m}$. The section size of grille column is $0.6 \mathrm{~m} \times 0.6 \mathrm{~m}$, and that of grille beam is $0.6 \mathrm{~m} \times 1.08 \mathrm{~m}$. The debris flow slurry is $10 \mathrm{~m}$ long, $6 \mathrm{~m}$ wide and $4 \mathrm{~m}$ high. The finite element model is shown in Fig. 1.

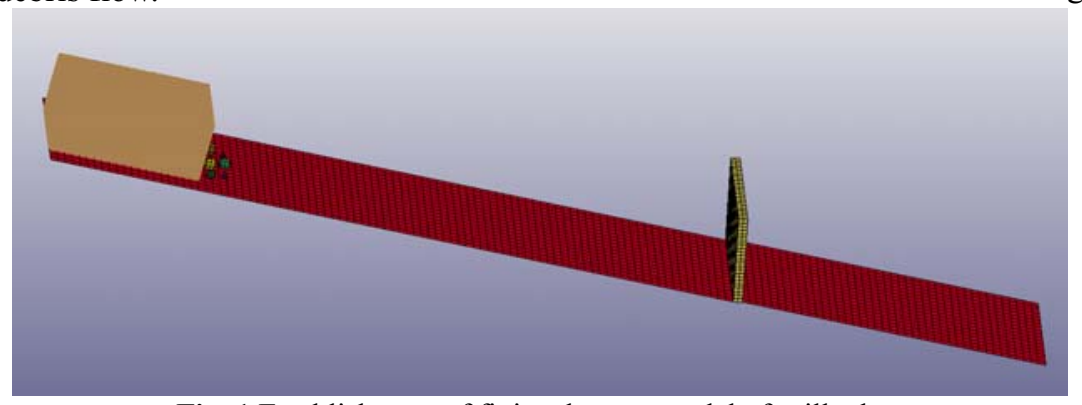

Fig. 1 Establishment of finite element model of grille dam

\footnotetext{
*Corresponding author: zhujia198325@163.com
} 
Shell 163 unit is used at the bottom of the river, and solid 164 unit is used for concrete and boulder. The model material parameters are shown in Table 1. The bottom of the river, the boulders and the dam are divided by hexahedral elements. The size of bottom 、 boulder、 dam are $500 \mathrm{~mm}, 400 \mathrm{~mm}$, and $300 \mathrm{~mm}$. The debris flow slurry is divided into $100 \mathrm{~mm}$ grilles and transformed into $\mathrm{SPH}$ particles in LS-PROPOST of LS-DYNA. In order to improve the calculation efficiency, the boundary of the model is simplified, and a fully fixed constraint is imposed on the bottom of the grille dam. The abutment of the grille dam is embedded into the mountains on both sides, so the full fixed constraint is imposed on the abutment on both sides of the grille dam. Considering the actual face-to-face contact between the boulder, river channel and grille dam, LS-DYNA automatic surface to surface contact is selected(ASTS):*CONTACT_AUTOMATIC_SURFACE TO SURFACE. Between slurry and the river channel, boulders and grille dam is the contact between the node and the surface, and the point-surface automatic contact is adopted:*CONTACT_AUTOMATIC_NODES_TO_SUR FACE.

Table 1. Material parameters

\begin{tabular}{|c|c|c|c|c|c|}
\hline number & $\begin{array}{c}\text { Density } \\
\left(\mathrm{kg} / \mathrm{m}^{3}\right)\end{array}$ & $\begin{array}{c}\text { Elastic modulus } \\
(\mathrm{Pa})\end{array}$ & $\begin{array}{c}\text { Poisson's } \\
\text { ratio }\end{array}$ & $\begin{array}{c}\text { Yield stress } \\
(\mathrm{Pa})\end{array}$ & $\begin{array}{c}\text { shear modulus } \\
(\mathrm{Pa})\end{array}$ \\
\hline bottom of the river & 3000 & $3 \mathrm{e} 10$ & 0.24 & -- & -- \\
\hline boulders & 3000 & $3 \mathrm{e} 10$ & 0.24 & -- & -- \\
\hline grille dam & 3000 & $3 \mathrm{e} 10$ & 0.2 & $5 \mathrm{e} 6$ & $0.63 \mathrm{e} 10$ \\
\hline debris flow slurry & 1600 & -- & -- & 90 & $1.68 \mathrm{e} 6$ \\
\hline
\end{tabular}

\section{Result analysis}

\subsection{Speed analysis}

Select three debris flow slurry nodes and boulders across the dam respectively, and draw its speed-time history curve, as shown in Fig. 2 and Fig. 3

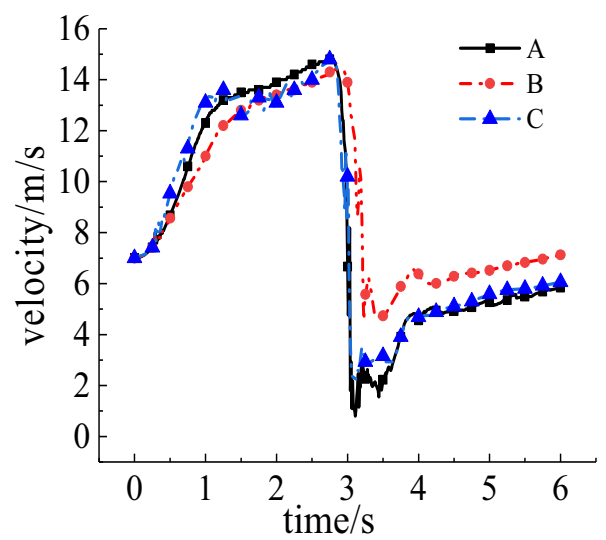

Fig. 2 Velocity of debris flow slurry nodes across the dam

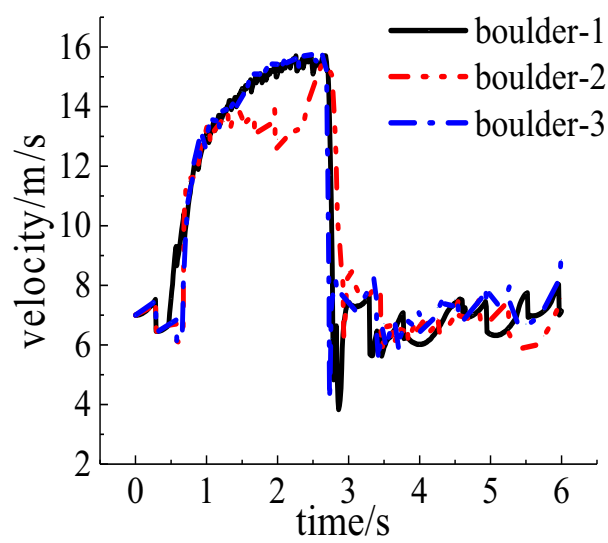

Fig. 3 Velocity of boulders across the dam
From the comparison of the velocities of $\mathrm{A}, \mathrm{B}$, and $\mathrm{C}$ slurry particles before and after passing through the dam, it is found that the velocity of particle A has dropped from $14.8 \mathrm{~m} / \mathrm{s}$ to $4.72 \mathrm{~m} / \mathrm{s}$, a decrease of $69 \%$; the velocity of particle B has dropped from $14.4 \mathrm{~m} / \mathrm{s}$ to $6.33 \mathrm{~m} / \mathrm{s}$, Reduced by $56 \%$; C particle velocity dropped from $14.8 \mathrm{~m} / \mathrm{s}$ to $4.66 \mathrm{~m} / \mathrm{s}$, a reduction of $68.5 \%$. From the comparison of the velocity of boulder-1, boulder- 2 and boulder- 3 before and after passing the dam, it is found that the velocity of boulder- 1 decreases by $63.8 \%$ from $15.7 \mathrm{~m} / \mathrm{s}$ to $5.69 \mathrm{~m} / \mathrm{s}$; the speed of boulder- 2 has dropped from $15.4 \mathrm{~m} / \mathrm{s}$ to $5.93 \mathrm{~m} / \mathrm{s}$, a decrease of $61.5 \%$; the speed of boulder-3 decreased from $15.9 \mathrm{~m} / \mathrm{s}$ to $5.79 \mathrm{~m} / \mathrm{s}$, a decrease of $63.6 \%$. It can be seen that the grille dam has a significant effect on reducing the velocity of slurry and boulders.

\subsection{Analysis of the Impact force}

Figures 4 and 5 are the time history curves of the impact force of debris flow slurry and boulder respectively.

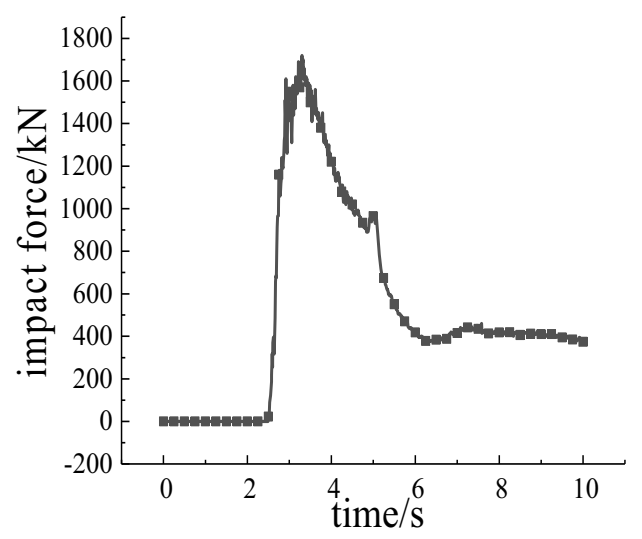

Fig. 4 Time-history curve of impact force of debris flow slurry 


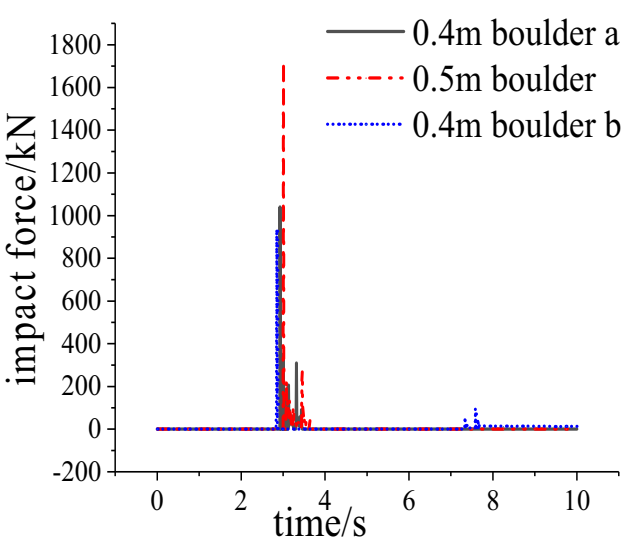

Fig.5 Comparison of boulder impact force

It can be seen from Fig. 4 that the main peak value of debris flow slurry impact force is $1724.2 \mathrm{kN}$. The debris flow slurry has climbing phenomenon in the process of impacting the grille dam. The climbing slurry has a secondary impact on the grille dam in the process of falling. The peak value of secondary impact load is $967.6 \mathrm{kN}$, and the impact force is reduced by $43.9 \%$.

It can be seen from Fig. 5 that the impact force of boulder b with radius of $0.4 \mathrm{~m}$ is $935 \mathrm{kN}$, that of boulder a with radius of $0.4 \mathrm{~m}$ is $1040 \mathrm{kN}$, and that of boulder with radius of $0.5 \mathrm{~m}$ is $1720 \mathrm{kN}$. Due to the effect of debris flow slurry on the boulders, the boulders still have a secondary impact. The secondary impact force of $0.4 \mathrm{~m}$ boulder $\mathrm{b}$ is $350 \mathrm{kN}$, the secondary impact force of $0.4 \mathrm{~m}$ boulder a is $310 \mathrm{kN}$, and the secondary impact force of $0.5 \mathrm{~m}$ boulder is $269 \mathrm{kN}$. From the boulder impact data, it can be seen that the larger the boulder radius, the greater the impact force, and the boulder radius increases by $0.1 \mathrm{~m}$, the impact force increases by nearly $800 \mathrm{kN}$. For the secondary impact, the impact force is not directly related to the size of the boulder radius.

\subsection{Support reaction analysis}

The Monitoring points for support reaction of the grille column are shown in Fig. 6, and the time-history curves of supports reaction are shown in Fig. 7.

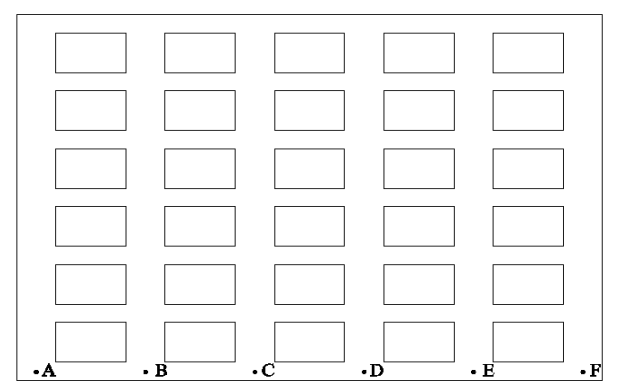

Fig. 6 Support reaction nodes selection diagram

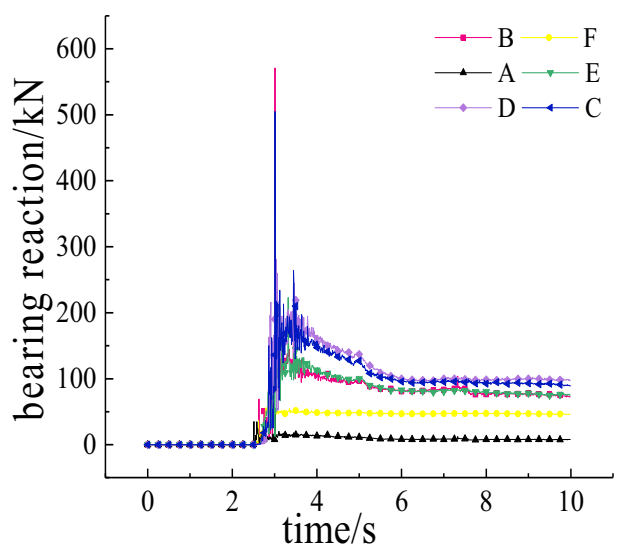

Fig. 7 Time-history curves of supports reaction

The results of the support reaction comparison are shown in Table 2.

Table 2. Support reaction comparison

\begin{tabular}{|c|c|c|c|c|c|c|}
\hline & A & B & C & D & E & F \\
\hline $\begin{array}{c}\text { Support } \\
\text { reaction } \\
(\mathrm{kN})\end{array}$ & 22 & 571 & 505 & 293 & 223 & 55.1 \\
\hline
\end{tabular}

In summary, the support reaction of side span grille columns is much smaller than that of middle columns; When the boulders impact on the grille column, the support reaction of the grille column is large, and the support reaction of the adjacent grille column is small. It shows that the spatial coordinate interaction between the grille columns can be ignored in the analyzing the force of the grille columns.

\section{Conclusions}

In this paper, the impact resistance of the grille dam based on the SPH-FEM fluid structure interaction method. Get the following conclusions:

(1) The grille dam has a significant effect on debris flow slurry and boulders. The speed of slurry and boulders have been reduced by nearly $60 \%$.

(2) The debris flow slurry and boulders have a secondary impact on the grille dam. For the first impact, the larger the radius of the boulder, the greater the impact force; For the secondary impact, there is no direct relationship between the impact force and the radius of the boulder.

(3) When the boulder hits the grille column, the reaction force of the grille column is relatively large, at the same time the reaction force of the adjacent grille column is small. It shows that the spatial coordinate interaction between the grille columns can be ignored in the process of analyzing the force of the grille columns.

\section{Acknowledgements}

Financial support from Industrial support program of higher education of Gansu province (2020C-40) is highly appreciated. 


\section{References}

1. Y.S. Wang, Y.P. Zhu, Y.N Wang. Seismic response analysis of a new ground anchor counterfort grilledam for debris flow under near-fault pulse-like ground motions, J. Hydraul. Eng, 42, S2: 162-167 (2012)

2. Y. Zhou, Z.L. Liu, X.L. Wang, F.X. Zhou. Dynamic response analysis for a dam against impact load of debris flow, Journal of Vibration and Shock, 34, 8: 117122 (2015)

3. Y.H. Ran, X.L. Wang, P. Wang. Experimental study on dynamic performance of concrete filled steel tubular piles under impact loads, Chinese Journal of Geotechnical Engineering, S1: 81-86 (2018)

4. J. Xu, Y.P. Zhu. Research on flow characteristics of Shangzhuo valley's debris flow and fluid-structure coupling numerical simulation, J. Hydraul. Eng, 46, S1: 248-254 (2015)

5. C. Liu, Z.X. Yu, L.R. Luo, S. Gu, S.C. Zhao. Dynamic behavior of a concrete dam impacted by debris flows with rock, Journal of Vibration and Shock, 38, 14: 161-168+238 (2019)

6. S. Feng, H.G. Wu, X.Y. Chen. A Numerical Analysis of Long Daban Ditch Debris Flow Sheet Pile Wall Blocking Structure Ultimate Punching, Science Technology and Engineering, 17, 31: 322-327 (2017) 